\title{
Accounting, Culture And Emerging Economies: IFRS In Central And Eastern Europe
}

David R. Borker, Manhattanville College, USA

\begin{abstract}
The work of Geert Hofstede and S.J. Gray has provided a framework for many studies of the potential impact of cultural values on accounting in various countries. This paper provides a comparative analysis of accounting perspectives in Central and Eastern European countries $(C E E C)$. The CEEC are former communist states in Europe which became independent countries after the collapse of the Iron Curtain. Twelve CEEC were selected for study: Bulgaria, Croatia, Czech Republic, Estonia, Hungary, Latvia, Lithuania, Poland, Romania, Serbia, Slovakia and Slovenia. Each is examined for Hofstede's six cultural dimensions and a corresponding accounting profile is derived based on Gray's accounting values. Profiles for each country are compared to an independent IFRS favorable profile proposed by the author as part of a broader analysis of cultural patterns, among other factors, for successful IFRS implementation.
\end{abstract}

Keywords: IFRS; Central and Eastern European Countries; CEEC; Accounting and Culture; Hofstede; Gray

\section{INTRODUCTION}

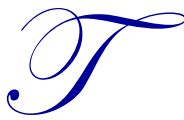

he Central and Eastern European Countries (CEEC) can be characterized as emerging transitional economies that moved out of Eastern Bloc domination in the 1990s and now aspire to full and continuing membership in the European Union (EU) (Hoskisson, Eden, Lau, \& Wright, 2000). Although each of these countries possesses its own distinct culture, all of the CEEC share the common experience of having functioned as command economies within the Soviet Union sphere of influence for at least two generations. In their transition toward the EU and greater acceptance by the global financial community, the CEEC appear to have excellent reasons to adopt International Financial Reporting Standards (IFRS) as the basis for public financial reporting, in as much as the European Commission began requiring the use of IFRS reporting in all EU member countries commencing in 2005 .

The goal of this study is to assess the effect that the specific cultural attributes of individual CEE countries, or groupings of CEEC, may have on successful adoption and implementation of IFRS. The means chosen to achieve this goal is to examine the cultural dimensional indices attributed to each of these countries using the six cultural value dimensions developed by Geert Hofstede (1980) and Hofstede, Hofstede, \& Minkov (2010) and the derived accounting culture value dimensions constructed by S. J. Gray (1988).

For this study, a sample set of twelve CEE countries was selected. The basis for the selection was the availability of Hofstede indices for all six Hofstede cultural dimensions. Geographically, the sample consists of three Baltic countries (Estonia, Latvia and Lithuania), five Balkan region states (Bulgaria, Croatia, Romania, Serbia, and Slovenia) and four contiguous Central European states (Poland, Czech Republic, Slovakia, and Hungary). All of these states are, or are in the process of becoming, European Union (EU) member states. They all require that International Financial Reporting Standards (IFRS) be used by at least some type(s) of entities in public financial reporting. In 2010, a survey of these countries was conducted by PriceWaterhouseCoopers (PWC, 2011). All of the countries in our CEEC sample group responded, except for Croatia. Respondents consistently referred to "IFRS as adopted by the EU" as the version of IFRS that they required, except for Serbia. Serbia stated that it required a local 
version of IFRS developed through convergence of Serbian GAAP with IFRS and indicated specific areas that needed to be updated to fully converge with IFRS. In keeping with the current level of acceptance by the EU, none of the respondents permit use of SME IFRS for regulatory reporting, although Estonia is working on its own proposals for SME IFRS and Serbia accepts its local IFRS for all companies. Although Croatia did not respond to the survey, the author was able to confirm, through Croatian accounting scholars that, in Croatia, large public companies are required to use IFRS for financial reporting, as well as regulatory reporting and that the version of IFRS required is that adopted by the EU. ${ }^{1}$

There exists some previous research literature on accounting and IFRS harmonization within the CEEC. This includes both general and comparative studies and country specific studies. General studies include topics such as harmonization of financial reporting, governance and regulatory processes (Larson \& Street, 2001; McGee, 2008; Bogdan \& Cristea, 2009; Strouhal, Dvorakova, \& Pasekova, 2011). One study discusses the impact of cultural variables on CEEC IFRS based on data from World Values Surveys (European_Value_Studies_Group \& World_Values_Survey_Association, 2006), but it does not use Hofstede and Gray as in this study (Bogdan \& Stefana-Maria, 2009). Selected individual CEEC studies of financial reporting and IFRS harmonization are indicated in Table I.

Table I: Previous Research by CEE Country

\begin{tabular}{|l|l|}
\hline \multicolumn{1}{|c|}{ Country } & \multicolumn{1}{c|}{ Research } \\
\hline Bulgaria & (Murphy, 2009) \\
\hline Croatia & $\begin{array}{l}\text { (Mosnja-Skare, 2001) (Barac \& Klepo, 2006) (Kovacic, 2010) (Plaats \& Nagy, 2011) (Barac \& Reljanovic, } \\
\text { 2012) (Pervan, 2012) }\end{array}$ \\
\hline Czech Republic & (Sucher \& Jindrichovska, 2004) (Strouhal, 2011) \\
\hline Estonia & (Alver \& Alver, 2011), Hungary (Beke, 2011) \\
\hline Latvia & (World_Bank, 2005) (Paupa, 2006) \\
\hline Lithuania & (Cernius, 2011) (Mackevicius, Zverovich, \& Kaslauskiene, 2011) \\
\hline Poland & (Moczarska, 2009) (Blechova, 2011) \\
\hline Romania & (Albu N., Albu, Bunea, Calu, \& Girbina, 2011) (Albu C. N., Albu, Gerbina, Bonaci, \& Mustata, 2011) \\
\hline Serbia & (Dragojević, Milenovic, \& Simic, 2006) (Andric, Mijic, \& Jaksic, 2011) \\
\hline Slovakia & (Baloghova, 2008) (Pasekova, 2011) \\
\hline Slovenia & (Garrod \& Turk, 1995) (Randelj, 2008) \\
\hline
\end{tabular}

Research on the topic of culture and its relationship to business and accounting has existed since the 1980s. In 1980, Geert Hofstede published his Culture's Consequences: International Differences in Work Related Values, based on data from individual questionnaires distributed to IBM managers and employees in 72 countries (Hofstede, 1980). Subsequently, S. Gray offered a hypothetical set of relationships between Hofstede's dimensions and his own culturally derived accounting value dimensions eight years later (Gray, 1988). Both Hofstede's original four dimensions and his subsequent work, including two more dimensions (Hodstede \& Bond, 1988; Hofstede, 2001; Hofstede \& Minkov, 2010), have been the subject of much research and debate (Sonderaard, 1994; Hofstede, 1994; Spector, 2001; Baskerville, 2003; Huang, 2007). Similarly, Gray's application of Hofstede's dimensional indices has led to extensive discussion, testing and application (Perera, 1989; Gray \& Vint, 1995;(Salter \& Niswander, 1995; Baydoun \& Willet, 1995; Emenyonu \& Gray, 1992; Zarzeski, 1996; Chanchani \& MacGregor, 1999; Hope, 2003; Doupnik \& Tsakumis, 2004; Chanchani \& Willet, 2004; Finch, 2009; Buys \& Schutte, 2011; Borker, 2012a.

\section{CULTURE AND ACCOUNTING: RESEARCH AND ANALYSIS}

Gray's association of accounting values, based on relationships to Hofstede's cultural dimensions (Hofstede, 1980), is founded on the argument that culture influences accounting. This stems from the general notion that societal values lead to the development and maintenance of institutions within a society, including educational, social, and political systems, and legal, financial, and corporate structures. Once in place, these systems reflect and reinforce societal values, and tend to be stable and remain in place, except where changes are caused by major external factors, such as international trade, investment, multinational companies, and colonization (Gray, 1988).

${ }^{1}$ These facts were confirmed by Dr. Zeljana A. Barac and Dr. Ivica Pervan of the University of Split, Split, Croatia. 
In his early research, Geert Hofstede (1980) identified four measurable cultural dimensions that differentiate cultures. The data upon which these dimensions were initially developed came from pencil and paper survey results collected within one large multinational business organization (IBM) in 72 countries, although subsequent surveys had a more diverse base. The four dimensions identified follow.

\section{Individualism versus Collectivism (IDV)}

The fundamental issue addressed by this dimension is the degree of interdependence that a society maintains among its members. It has to do with whether people's self-image is defined in terms of "I" or "We". In individualist societies, people are supposed to only look after themselves and their direct family. In collectivist societies, people belong to 'in groups' that care for them in exchange for loyalty.

\section{Power Distance (PDI)}

This dimension deals with the fact that all individuals in societies are not equal. It expresses the attitude of the culture toward these inequalities among us. Power distance is defined as the extent to which the less powerful members of institutions and organizations within a country expect and accept that power is distributed unequally.

\section{Masculinity versus Femininity (MAS)}

A high score (masculine) on this dimension indicates that the society is driven by competition, achievement and success, with success being defined by the winner/best in field - a value system that starts in school and continues throughout organizational behavior. A low score (feminine) on this dimension means that the dominant values in society are caring for others and quality of life. A feminine society is one in which quality of life is the sign of success. Standing out from the crowd is not admirable. The fundamental issue here is what motivates people; i.e., wanting to be the best (masculine) or liking what you do (feminine).

\section{Uncertainty Avoidance (UAI)}

This dimension deals with the way a society considers the fact that the future can never be known; i.e., should we try to control the future or just let it happen? This ambiguity brings anxiety with it and different cultures have learned to deal with this anxiety in different ways. The extent to which the members of a culture feel threatened by ambiguous or unknown situations and have created beliefs and institutions that try to avoid these is reflected in the UAI score (Hofstede, 2001).

Subsequently, the following two additional cultural dimensions were established by Hofstede and his associates (Hofstede, Hofstede, \& Minkov, 2010).

\section{Long-term versus Short-term Orientation (LTO)}

The long-term orientation dimension is closely related to the teachings of Confucius and can be interpreted as dealing with society's search for virtue; i.e., the extent to which a society shows a pragmatic future-oriented perspective rather than a conventional historical short-term point of view (Hofstede, Hofstede, \& Minkov, 2010).

\section{Indulgence versus Restraint (IVR)}

The indulgence versus restraint dimension consists of two poles. Indulgence stands for a tendency to allow relatively free gratification of basic and natural human desires related to enjoying life and having fun, and the opposite pole. Restraint reflects a conviction that such gratification needs to be curbed and regulated by strict norms (Hofstede, Hofstede, \& Minkov, 2010).

Extending the concepts of Hofstede's original four dimensions to accounting, Gray suggests that accounting values are derived from such cultural dimensions and, in turn, influence accounting systems. Gray identifies four key accounting values or dimensions (Gray, 1988). 
Professionalism versus Statutory Control refers to professional judgment and self-regulation in contrast to compliance with rigid legal requirements and legislative control.

Uniformity versus Flexibility is the level of enforcement of standardized and consistent accounting practices.

Conservatism versus Optimism is a vigilant approach to accounting measurement, as opposed to a more optimistic and risk-taking approach.

Secrecy versus Transparency is confidentiality and the constraint of disclosure of information, as opposed to a more transparent and publicly accountable approach.

Considering this interaction between the Hofstede cultural dimensions and his own accounting values, Gray offered the hypotheses (Gray,1988) summarized in Table II.

Table II: Summary of Gray's Hypotheses

\begin{tabular}{|l|l|}
\hline Hypothesis I & $\begin{array}{l}\text { The higher a ranking in terms of individualism and the lower the ranking in terms of uncertainty } \\
\text { avoidance and power distance, the more likely the country is to rank highly in terms of professionalism. }\end{array}$ \\
\hline Hypothesis II & $\begin{array}{l}\text { The higher a ranking in terms of uncertainty avoidance and power distance and the lower the ranking in } \\
\text { terms of individualism, the more likely it is to rank highly in terms of uniformity. }\end{array}$ \\
\hline Hypothesis III & $\begin{array}{l}\text { The higher a ranking in terms of uncertainty avoidance and the lower the ranking in terms of } \\
\text { individualism and masculinity, the more likely it is to rank highly in terms of conservatism. }\end{array}$ \\
\hline Hypothesis IV & $\begin{array}{l}\text { The higher a ranking in terms of uncertainty avoidance and power distance and the lower the ranking in } \\
\text { terms of individualism and masculinity, the more likely it is to rank highly in terms of secrecy. }\end{array}$ \\
\hline
\end{tabular}

Elements of the above hypotheses can be summarized in table format where each of Grays accounting values are rows and each of Hofstede's dimensions are columns. In accordance with Gray's hypotheses, cells in the table are populated using (+) as positive or direct relationship, (-) as negative or inverse, or (?) as undetermined relationship to one another (Baydoun \& Willet, 1995). Where a specific dimension is identified by Gray as having a stronger relationship, a double plus $(++)$ or double minus $(--)$ is used (Borker, 2012a). The undetermined relationship (?) indicates that Gray has not made any connection between that Hofstede dimension and the specific accounting value as reflected in Table III.

Table III: Hofstede-Gray Relationships

\begin{tabular}{|l|c|c|c|c|}
\hline & $\begin{array}{c}\text { Power Distance } \\
\text { PDI }\end{array}$ & $\begin{array}{c}\text { Individualism } \\
\text { IDV }\end{array}$ & $\begin{array}{c}\text { Masculinity } \\
\text { MAS }\end{array}$ & $\begin{array}{c}\text { Uncertainty Avoidance } \\
\text { UAI }\end{array}$ \\
\hline Conservatism & + & - & - & ++ \\
\hline Uniformity & + & -- & $?$ & ++ \\
\hline Professionalism & - & ++ & $?$ & -- \\
\hline Secrecy & ++ & -- & - & ++ \\
\hline
\end{tabular}

In his original article, Gray notes that the accounting value of Optimism (opposite of Conservatism), Flexibility (opposite of Uniformity), Professionalism and Transparency (opposite of Secrecy) are characteristic of the Anglo-Saxon Accounting tradition. These consist of the United States, the United Kingdom, and commonwealth countries (Gray, 1988). All of these are societies with strong democratic values with a long-standing tradition of publically-traded stock companies and an emphasis on financial reporting that meets the needs of individual equity investors.

Hofstede's dimensional indices for these countries are extremely consistent, not only for the original four dimensions used by Gray in deriving his accounting value dimensions, but also for the fifth and sixth cultural dimensions developed subsequently (Borker manuscript). Table IV summarizes Hofstede's six dimensional indices for these countries. 
Table IV: Hofstede Six Dimensional Indices for Anglo-Saxon Accounting Tradition Countries

\begin{tabular}{|l|c|c|c|c|c|c|}
\hline $\begin{array}{c}\text { Anglo- } \\
\text { Accounting } \\
\text { Countries }\end{array}$ & $\begin{array}{c}\text { Power } \\
\text { Distance } \\
\text { PDI }\end{array}$ & $\begin{array}{c}\text { Individualism } \\
\text { IDV }\end{array}$ & $\begin{array}{c}\text { Masculinity } \\
\text { MAS }\end{array}$ & $\begin{array}{c}\text { Uncertainty } \\
\text { Avoidance } \\
\text { UAI }\end{array}$ & $\begin{array}{c}\text { Long-Term } \\
\text { Orientation } \\
\text { LTO }\end{array}$ & $\begin{array}{c}\text { Indulgence vs. } \\
\text { Restraint } \\
\text { IVR }\end{array}$ \\
\hline Australia & 36 & 90 & 61 & 51 & 21 & 71 \\
\hline Canada & 39 & 80 & 52 & 48 & 36 & \\
\hline New Zealand & 22 & 79 & 58 & 49 & 33 & 6 \\
\hline United Kingdom & 35 & 89 & 66 & 35 & 51 & 75 \\
\hline United States & 40 & 91 & 62 & 46 & 26 & 6 \\
\hline
\end{tabular}

Given the high degree of uniformity in the indices for all six Hofstede cultural dimensions, Table I can be expanded to include the relationship between Gray's four accounting dimensions and Hofstede's fifth and six cultural dimensions. This expanded mapping is provided in Table V (Borker manuscript).

Table V: Expansion of Hofstede-Gray Relationships

\begin{tabular}{|l|c|c|c|c|c|c|}
\hline & $\begin{array}{c}\text { Power } \\
\text { Distance } \\
\text { PDI }\end{array}$ & $\begin{array}{c}\text { Individualism } \\
\text { IDV }\end{array}$ & $\begin{array}{c}\text { Masculinity } \\
\text { MAS }\end{array}$ & $\begin{array}{c}\text { Uncertainty } \\
\text { Avoidance } \\
\text { UAI }\end{array}$ & $\begin{array}{c}\text { Long-Term } \\
\text { Orientation } \\
\text { LTO }\end{array}$ & $\begin{array}{c}\text { Indulgence vs. } \\
\text { Restraint } \\
\text { IVR }\end{array}$ \\
\hline Conservatism & + & - & - & ++ & + & - \\
\hline Uniformity & + & -- & $?$ & ++ & + & - \\
\hline Professionalism & - & ++ & $?$ & -- & - & + \\
\hline Secrecy & ++ & -- & - & ++ & + & + \\
\hline
\end{tabular}

In addition to supporting the expansion of Hofstede-Gray relationships to include Hofstede's fifth and sixth cultural dimensions, the profile of the Anglo-Saxon Accounting countries in Table V is also the basis for proposing a favorable cultural profile based on Gray accounting values for the establishment of IFRS-based accounting systems. An IFRS favorable profile using Gray accounting values is summarized in Table VI (Borker, 2012a; (Borker manuscript).

Table VI: IFRS Favorable Accounting Value Profile based on Gray's Four Original Values Dimensions

\begin{tabular}{|l|c|}
\hline \multicolumn{1}{|c|}{ Hypotheses/ Gray Accounting Dimensions } & IFRS Favorable Profile \\
\hline H1 Professionalism vs. Statutory Control & Professionalism \\
\hline H2 Uniformity versus Flexibility & Flexibility \\
\hline H3 Conservatism versus Optimism & Optimism $^{2}$ \\
\hline H4 Secrecy versus Transparency & Transparency \\
\hline
\end{tabular}

This IFRS favorable profile is used as a point of reference and comparison in analyzing results from the CEEC analysis.

\section{CURRENT ANALYSIS RESULTS}

\section{Results and Analysis of Central and East European Countries: Hofstede Cultural Dimensions}

The Hofstede cultural dimension scores of the CEEC are presented in Table VII. Definitions and discussion of the dimensions of each CEEC country in the section that follows are taken directly from Hofstede (2001; Hofstede, Hofstede, \& Minkov, 2010). Analytical statements comparing the CEEC countries within each dimension are those of the author.

\footnotetext{
${ }^{2}$ Although conservatism is, on some level, basic to all accounting systems, Optimism is assumed to reflect a greater openness to new ways of measuring and evaluating, such as fair value accounting. This is seen as characteristic of the openness to change and evolution of standards in IFRS and U.S. GAAP.
}

(C) 2012 The Clute Institute http://www.cluteinstitute.com/ 
Table VII: Results of Hofstede Six Cultural Dimensions for CEEC

\begin{tabular}{|c|c|c|c|c|c|c|}
\hline CEEC & $\begin{array}{c}\text { Power } \\
\text { Distance } \\
\text { PDI }\end{array}$ & $\begin{array}{c}\text { Individualism } \\
\text { IDV }\end{array}$ & $\begin{array}{l}\text { Masculinity } \\
\text { MAS }\end{array}$ & $\begin{array}{c}\text { Uncertainty } \\
\text { Avoidance } \\
\text { UAI }\end{array}$ & $\begin{array}{c}\text { Long-Term } \\
\text { Orientation } \\
\text { LTO }\end{array}$ & $\begin{array}{c}\text { Indulgence vs. } \\
\text { Restraint } \\
\text { IVR }\end{array}$ \\
\hline Bulgaria & 70 & 30 & 40 & 85 & 69 & 16 \\
\hline Croatia & 73 & 33 & 40 & 80 & 58 & 33 \\
\hline Czech Republic & 57 & 58 & 57 & 74 & 70 & 29 \\
\hline Estonia & 40 & 60 & 30 & 60 & 82 & 16 \\
\hline Hungary & 46 & 80 & 88 & 82 & 58 & 31 \\
\hline Latvia & 44 & 70 & 9 & 63 & 69 & 13 \\
\hline Lithuania & 42 & 60 & 19 & 65 & 82 & 16 \\
\hline Poland & 68 & 60 & 64 & 93 & 38 & 29 \\
\hline Romania & 90 & 30 & 42 & 90 & 52 & 20 \\
\hline Serbia & 86 & 25 & 43 & 92 & 52 & 28 \\
\hline Slovakia & 104 & 52 & 110 & 51 & 77 & 28 \\
\hline Slovenia & 71 & 27 & 19 & 88 & 49 & 48 \\
\hline
\end{tabular}

\section{Analysis of Hofstede Results CEEC States}

\section{Power Distance (PDI)}

With the exception of Hungary and the three Baltic states (Estonia, Latvia and Lithuania), with scores ranging from 40 to 46, all other countries in the CEEC sample have relatively high PDI, with scores ranging from 57 to 104. High Power Distance is typical of Russia and many of its former Soviet republics, excluding the Baltics. It is therefore not surprising that this feature should be prevalent in the CEEC. It is noteworthy that the Baltic States and Hungary do not conform to this pattern.

\section{Individualism versus Collectivism (IDV)}

The CEEC sample can be split down the middle into two distinct groups for this dimension, with half the group tending toward individualism, with scores ranging from 52 to 80, and half leaning toward collectivism, with scores ranging from 25 to 33 . Hofstede notes that there is a significant negative correlation between the PDI and IDV dimensions. This is evidenced in the CEEC where nine of the 12 countries have either high PDI and low IDV or high IDV and low PDI. Exceptions are Slovakia, Poland, and the Czech Republic, all of which have high PDI and high IDV.

\section{Masculine versus Feminine (MAS)}

Except for a regional grouping of Poland, Czech Republic, Slovakia, and Hungary, with scores ranging from 57 to 110, all of the remaining eight countries from the CEEC sample are characterized by low masculinity, with scores ranging from 9 to 43 . In contrast to the success orientation of a high masculine score, feminine orientation means that the dominant values in society are caring for others and quality of life. Doing something you like to do is valued over being the best.

\section{Uncertainty Avoidance (UAI)}

All countries in the CEEC sample lean toward uncertainty avoidance, with scores ranging from 51 to 92. The group can, however, be divided into a lower group of five countries, with scores ranging from 51 to 74 , and a higher group of seven countries, with scores ranging from 80 to 92 . The extent to which the members of a culture feel threatened by ambiguous or unknown situations and have created beliefs and institutions that try to avoid these is reflected in the UAI index. Society may adopt laws and controls to avoid uncertainty. 


\section{Long-Term Orientation (LTO)}

All the CEEC except Slovenia, with a score 49, lean toward long-term orientation, with scores ranging from 51 to 88 . The long-term orientation dimension can be interpreted as dealing with society's search for virtue, the extent to which a society shows a pragmatic future-oriented perspective rather than a conventional historical shortterm point of view. These societies emphasize traditions and saving for the future. Most western cultures lean toward a more concrete historical focus that often emphasizes a more black-and-white bottom-line orientation.

\section{Indulgence vs. Restraint (IVR}

All countries in the CEEC sample lean toward restraint, with scores ranging from 16 to 48 . Indulgence indicates a tendency to enjoy life and be happy. Its opposite - restraint - reflects a conviction that such gratification needs to be curbed and regulated by strict norms. Interestingly, the lowest score on this dimension in the total population of countries examined by Hofstede was Pakistan which had a score of zero. In a region characterized by what could be seen as a rather low "happiness index," Slovenia's score of 48 might seem noteworthy.

\section{Results and Analysis of Central And East European Countries:}

\section{Gray Four Accounting Dimensions For CEEC}

This section converts the Hofstede cultural dimensions identified with individual CEEC to the accounting value dimensions proposed by Gray to explain and predict the development of different accounting systems (Gray, 1988) considering Hofstede's original four cultural dimensions. This analysis considers both the relative position of the 12 CEEC sample to one another and takes into consideration the larger population of all countries for which Hofstede has established scores for his first four dimensions. The matrix of relationships between Gray and Hofstede dimensions (Table I) is utilized and the greater importance of certain Hofstede dimensions over others, indicated by a double plus or double minus sign, is given greater weight in the analysis. Based on this examination, the following attributions of Gray accounting values are proposed for the CEEC in Table VIII. Results are indicated by the first three letters of the accounting value and are modified downward by one or more minuses. In cases where the result is midway between the two value polarities of the dimension, both values are indicated separated by a slash, with the order determined by which of the two appears to be slightly stronger.

Table VIII: Results of Gray Accounting Values for each CEEC based on Gray Original Four Dimensions

\begin{tabular}{|l|c|c|c|c|}
\hline \multicolumn{1}{|c|}{ CEE Countries } & $\begin{array}{c}\text { Professionalism versus } \\
\text { Statutory Control }\end{array}$ & $\begin{array}{c}\text { Uniformity versus } \\
\text { Flexibility }\end{array}$ & $\begin{array}{c}\text { Conservatism versus } \\
\text { Optimism }\end{array}$ & $\begin{array}{c}\text { Secrecy versus } \\
\text { Transparency }\end{array}$ \\
\hline Bulgaria & Statutory Control & Uniformity & Conservatism & Secrecy \\
\hline Croatia & Statutory Control & Uniformity/Flexibility & Conservatism & Secrecy \\
\hline Czech Republic & $\begin{array}{c}\text { Statutory } \\
\text { Control/Professionalism }\end{array}$ & Flexibility & Conservatism/Optimism & Transparency (-) \\
\hline Estonia & Professionalism & Flexibility & Optimism & Transparency \\
\hline Hungary & Professionalism & Flexibility & Optimism & Transparency \\
\hline Latvia & Professionalism & Flexibility & Conservatism/Optimism & Transparency \\
\hline Lithuania & Professionalism & Uniformity(-) & Conservatism/Optimism & Transparency \\
\hline Poland & Statutory Control (-) & Uniformity & Conservatism (-) & Secrecy (-) \\
\hline Romania & Statutory Control & Uniformity & Conservatism & Secrecy \\
\hline Serbia & Statutory Control & Uniformity (-) & Conservatism & Secrecy \\
\hline Slovakia & Statutory Control & Uniformity & Optimism & Secrecy/Transparency \\
\hline Slovenia & Statutory Control & Flexibility & Conservatism & Secrecy \\
\hline
\end{tabular}

\section{Analysis of Gray Results}

Two primary patterns can be identified in the Gray attribute configurations or profiles attributed to the individual CEEC. The first pattern is that of Statutory Control, Uniformity, Conservatism, and Secrecy. Five of the countries exhibit this pattern fully, except for minor variations. They are Bulgaria, Croatia, Poland, Romania, and Serbia. Slovakia and Slovenia each share three of the four components of this profile, with Slovakia differing due to 
optimism and Slovenia due to flexibility. This group, as a whole, exhibits the opposite pattern to that of the IFRS favorable profile identified in Table V. Taken as a group, these seven countries comprise all of the Balkan countries in the CEEC sample and Poland and Slovakia.

A second pattern that is observed in the CEEC sample is that of Professionalism, Flexibility, Optimism, and Transparency. This pattern is consistent with the IFRS favorable profile identified in Table VI. It is fully realized for Estonia and Hungary with Latvia exhibiting all components, except for a split result for Conservatism/Optimism. Also, Lithuania and the Czech Republic both share two of the three components of this profile with split results for the other two. Taken as a group, these five comprise all of the Baltic states, Hungary, and the Czech Republic.

\section{Including Hofstede's Fifth and Sixth Dimensions in Gray Valuations of CEEC}

It was decided not to include proposed relationships between Gray's values and Hofstede's Long-Term Orientation and Indulgence versus Restraint dimensions in attributing Gray's values to the CEEC sample. This was done primarily to avoid issues of the proper weighting of these extensions to Gray's hypotheses. A second reason has to do with the availability of conflicting data on the Long-Term Orientation dimension on the Internet. Numbers reported in this paper are taken from Hofstede's own certified downloadable spreadsheet results for all countries measured and are certified to be correct. Nonetheless, it was felt prudent to refrain from including this data in the estimating process. It should be noted, however, that if the results had been included, they would, for the most part, have had a uniform effect of increasing the distance of all countries' results from the IFRS-favorable profile. A minor exception to this pattern is Slovenia, which exhibited a borderline short-term orientation score of 49 .

\section{DISCUSSION}

\section{Hofstede Six dimensions and CEEC}

Hofstede's country data for the six dimensions are analyzed in terms of pairings of two dimensions - one on the vertical and one on the horizontal axis in such a way as to divide the plotted data for worldwide countries into four quadrants. The seven dimensional pairings analyzed by Hofstede are (1) PDI versus UAI, (2) UAI versus IDV, (3) MAS versus UAI, (4) PDI versus MAS, (5) MAS versus IDV, (6) PDI versus IDV, and (7) IVR versus LTO. The groupings of CEEC versus other countries can further contribute to our understanding of the CEEC cultural attributes.

\section{Russia-oriented Group}

Based on Hofstede's dimensional pairings, five of the CEE countries showed a strong similarity to Russia in terms of the number of dimensional pairings in which they were in the same quadrant as Russia. These countries were Bulgaria, Croatia, Romania, Serbia, and Slovenia, each of which was similar to Russia in seven out of seven pairings, or in the case of Slovenia, six out of seven. These five countries are all located in the Balkan region of Europe.

\section{Predominantly Not Russia-oriented Group}

The remaining seven CEE countries have a relatively lower number of dimensional pairings similar to Russia. These countries each had no more than one or two such similar pairings. All of these countries exhibited stronger positional similarities to dimensional pairings of various other Western European countries or regional groupings. The two detectable subgroups of the Not Russia-oriented group were (a) a Scandinavia-oriented subgroup (based on proxy of Sweden that has dimensional scores representative of the Scandinavian countries) that all shared a similar position in five out of seven dimensional parings provided by Hofstede, consisting of Estonia, Latvia, and Lithuania and (b) a Germany-oriented subgroup that shared a similar position for three to six Hofstede dimensional pairings, consisting of Hungary, Czech Republic, Poland, and Slovakia. Of the second group, Hungary is close to Germany on six dimensional pairings and the Czech Republic on four. Poland and Slovakia have only three, while having three and two, respectively, in common with various other countries. All four of these countries are contiguous to one another and share a common history of having been part of the Hapsburg Empire. On the other hand, the cultural similarity of the Baltic countries to Finland and Sweden is not surprising. In the case of 
Estonia, there is a linguistic tie with Finland since both Estonian and Finnish are Finno-Ugric languages. It should also be noted that, in addition to being close to the Scandinavian countries on five out of seven Hofstede dimension pairings, the Baltic countries are each close to Germany on three out of seven Hofstede pairings.

\section{Gray Dimensions and CEEC}

In order to review and evaluate the results of the above analysis, it is necessary to return to the basic intension of Gray's four hypotheses and his accounting value dimensions. These dimensions are not designed to identify positive versus negative influences on accounting. Rather, Gray's dimensions characterize different contrasting aspects of accounting values that can affect the development of accounting systems in different directions. Each value can be seen as reflecting both advantages and disadvantages associated with systems of accounting. Conservatism is acknowledged as an old and venerated accounting value associated with care, caution, and prudence. At the same time, it leaves little room for creativity or new ways of solving reporting problems. Nevertheless, as noted above, a specific combination of Gray attributes, identified with the Anglo-Saxon Accounting countries, can be identified as the favorable IFRS profile shown in Table VI in that they characterize cultures which, disregarding external influences and other special internal factors, would tend to develop accounting systems oriented toward IFRS accounting values.

On the basis of Tables V and VIII, as well as the relationships between Hofstede dimensions and Gray's four accounting dimensions, the following set of rankings can be developed for the CEEC in terms of the predicted level of cultural fit between each country and IFRS standards. These rankings are summarized in Table IX which identifies each CEEC in terms of affinity groups and subgroups observed in the discussion of Hofstede's four quadrant dimensional pairings.

Table IX: CEEC Listed from Closest to Most Remote from IFRS Favorable Profile by Rank

\begin{tabular}{|c|c|c|c|c|c|c|}
\hline $\begin{array}{c}\text { CEE } \\
\text { Country/ }\end{array}$ & Group & Subgroup & \multicolumn{2}{|c|}{ Individual Country Profile } & \multicolumn{2}{|c|}{ IFRS Favorable Profile } \\
\hline Hungary & $\begin{array}{l}\text { Not Russia- } \\
\text { oriented }\end{array}$ & $\begin{array}{l}\text { Germany- } \\
\text { oriented }\end{array}$ & $\begin{array}{l}\text { Professionalism } \\
\text { Optimism }\end{array}$ & $\begin{array}{l}\text { Flexibility } \\
\text { Transparency }\end{array}$ & $\begin{array}{l}\text { Professionalism } \\
\text { Optimism }\end{array}$ & $\begin{array}{l}\text { Flexibility } \\
\text { Transparency }\end{array}$ \\
\hline Estonia & $\begin{array}{l}\text { Not Russia- } \\
\text { oriented }\end{array}$ & $\begin{array}{l}\text { Scandinavia- } \\
\text { oriented }\end{array}$ & $\begin{array}{l}\text { Professionalism } \\
\text { Optimism }\end{array}$ & $\begin{array}{l}\text { Flexibility } \\
\text { Transparency }\end{array}$ & $\begin{array}{l}\text { Professionalism } \\
\text { Optimism }\end{array}$ & $\begin{array}{l}\text { Flexibility } \\
\text { Transparency }\end{array}$ \\
\hline Latvia & $\begin{array}{l}\text { Not Russia- } \\
\text { oriented }\end{array}$ & $\begin{array}{l}\text { Scandinavia- } \\
\text { oriented }\end{array}$ & $\begin{array}{l}\text { Professionalism } \\
\text { Conservatism/Optimism }\end{array}$ & $\begin{array}{l}\text { Flexibility } \\
\text { Transparency }\end{array}$ & $\begin{array}{l}\text { Professionalism } \\
\text { Optimism }\end{array}$ & $\begin{array}{l}\text { Flexibility } \\
\text { Transparency }\end{array}$ \\
\hline $\begin{array}{l}\text { Czech } \\
\text { Republic }\end{array}$ & $\begin{array}{l}\text { Not Russia- } \\
\text { oriented }\end{array}$ & $\begin{array}{l}\text { Germany- } \\
\text { oriented }\end{array}$ & $\begin{array}{l}\text { Statutory Control/ } \\
\text { Professionalism } \\
\text { Conservatism/Optimism }\end{array}$ & $\begin{array}{l}\text { Flexibility } \\
\text { Transparency }\end{array}$ & $\begin{array}{l}\text { Professionalism } \\
\text { Optimism }\end{array}$ & $\begin{array}{l}\text { Flexibility } \\
\text { Transparency }\end{array}$ \\
\hline Lithuania & $\begin{array}{l}\text { Not Russia- } \\
\text { oriented }\end{array}$ & $\begin{array}{l}\text { Scandinavia- } \\
\text { oriented }\end{array}$ & $\begin{array}{l}\text { Professionalism } \\
\text { Optimism }\end{array}$ & $\begin{array}{l}\text { Uniformity(-) } \\
\text { Transparency }\end{array}$ & $\begin{array}{l}\text { Professionalism } \\
\text { Optimism }\end{array}$ & $\begin{array}{l}\text { Flexibility } \\
\text { Transparency }\end{array}$ \\
\hline Slovakia & $\begin{array}{l}\text { Not Russia- } \\
\text { oriented }\end{array}$ & $\begin{array}{l}\text { Germany- } \\
\text { oriented }\end{array}$ & $\begin{array}{l}\text { Statutory Control } \\
\text { Conservatism } \\
\end{array}$ & $\begin{array}{l}\text { Uniformity } \\
\text { Secrecy/Transparency }\end{array}$ & $\begin{array}{l}\text { Professionalism } \\
\text { Optimism } \\
\end{array}$ & $\begin{array}{l}\text { Flexibility } \\
\text { Transparency }\end{array}$ \\
\hline Poland & $\begin{array}{l}\text { Not Russia- } \\
\text { oriented }\end{array}$ & $\begin{array}{l}\text { Germany- } \\
\text { oriented }\end{array}$ & $\begin{array}{l}\text { Statutory Control } \\
\text { Conservatism }\end{array}$ & $\begin{array}{l}\text { Uniformity } \\
\text { Secrecy }\end{array}$ & $\begin{array}{l}\text { Professionalism } \\
\text { Optimism }\end{array}$ & $\begin{array}{l}\text { Flexibility } \\
\text { Transparency }\end{array}$ \\
\hline Slovenia & $\begin{array}{l}\text { Russia- } \\
\text { oriented }\end{array}$ & None & $\begin{array}{l}\text { Statutory Control(-) } \\
\text { Conservatism }\end{array}$ & $\begin{array}{l}\text { Flexibility } \\
\text { Secrecy (-) }\end{array}$ & $\begin{array}{l}\text { Professionalism } \\
\text { Optimism }\end{array}$ & $\begin{array}{l}\text { Flexibility } \\
\text { Transparency }\end{array}$ \\
\hline Croatia & $\begin{array}{l}\text { Russia- } \\
\text { oriented }\end{array}$ & None & $\begin{array}{l}\text { Statutory Control } \\
\text { Conservatism }\end{array}$ & $\begin{array}{l}\text { Uniformity/Flexibility } \\
\text { Secrecy }\end{array}$ & $\begin{array}{l}\text { Professionalism } \\
\text { Optimism }\end{array}$ & $\begin{array}{l}\text { Flexibility } \\
\text { Transparency }\end{array}$ \\
\hline Bulgaria & $\begin{array}{l}\text { Russia- } \\
\text { oriented }\end{array}$ & None & $\begin{array}{l}\text { Statutory Control } \\
\text { Conservatism }\end{array}$ & $\begin{array}{l}\text { Uniformity } \\
\text { Secrecy }\end{array}$ & $\begin{array}{l}\text { Professionalism } \\
\text { Optimism }\end{array}$ & $\begin{array}{l}\text { Flexibility } \\
\text { Transparency }\end{array}$ \\
\hline Serbia & $\begin{array}{l}\text { Russia- } \\
\text { oriented }\end{array}$ & None & $\begin{array}{l}\text { Statutory Control } \\
\text { Conservatism }\end{array}$ & $\begin{array}{l}\text { Uniformity } \\
\text { Secrecy }\end{array}$ & $\begin{array}{l}\text { Professionalism } \\
\text { Optimism }\end{array}$ & $\begin{array}{l}\text { Flexibility } \\
\text { Transparency }\end{array}$ \\
\hline Romania & $\begin{array}{l}\text { Russia- } \\
\text { oriented }\end{array}$ & None & $\begin{array}{l}\text { Statutory Control } \\
\text { Conservatism }\end{array}$ & $\begin{array}{l}\text { Uniformity } \\
\text { Secrecy }\end{array}$ & $\begin{array}{l}\text { Professionalism } \\
\text { Optimism }\end{array}$ & $\begin{array}{l}\text { Flexibility } \\
\text { Transparency }\end{array}$ \\
\hline
\end{tabular}

All of the CEE countries from the Not Russia-oriented category rank ahead of the CEE countries identified as having a Russia orientation. There is no distinct pattern associated with the rankings based on the two Not Russia-oriented subgroups, except that, among those countries identified as being Germany-oriented, Poland and Slovakia have the lowest rankings. As noted above, Poland and Slovakia have the smallest number of dimensional 
pairing positions within this group similar to Germany, and may be viewed as only marginal members of the group. Of the CEEC that are characterized as being Russia-oriented, the predominant accounting values are statutory control, uniformity, conservatism, and secrecy. This is the same accounting value profile found for Russia based on Gray's dimensions derived from Hofstede cultural dimension indices for Russia.

For purposes of comparison, a summary of Gray-based accounting value profiles for Germany, Sweden (proxy for Scandinavian countries), and Russia is provided in Table X.

Table X: Profiles for Germany Sweden and Russia Compared with IFRS Favorable Profile

\begin{tabular}{|l|ll|ll|}
\hline CEE Country/ & \multicolumn{2}{|c|}{ Individual Country Profile } & \multicolumn{2}{c|}{ IFRS Favorable Profile } \\
\hline Germany & Professionalism & Flexibility & Professionalism & Flexibility \\
& Optimism/Conservatism & Transparency & Optimism & Transparency \\
\hline Sweden & Professionalism & Flexibility/Uniformity & Professionalism & Flexibility \\
& Optimism & Transparency & Optimism & Transparency \\
\hline Russia & Statutory control & Uniformity & Professionalism & Flexibility \\
& Conservatism & Secrecy & Optimism & Transparency \\
\hline
\end{tabular}

In contrast to Russia, the profiles for Sweden and Germany are much closer to the IFRS profile. Germany and Sweden were selected as countries or regions with cultural affinities affecting profiles for subgroups of the Not Russia-oriented CEEC.

\section{Significance of Variances to IFRS Profile on IFRS Implementation}

The five countries in the Russia-oriented group of the CEEC sample - Serbia, Romania, Bulgaria, Croatia, and Slovenia - share with Russia accounting values that are opposite from and, consequently, most remote from the accounting value orientation likely to lead to the independent development of accounting systems and standards, like IFRS. This does not mean that outside influences and special developments within these countries cannot motivate them to adopt or converge with IFRS and successfully implement IFRS for their accounting and financial reporting. Nonetheless, countries with cultural accounting values more remote from the IFRS value profile may have more to overcome in adopting and continuing to evolve with IFRS since, by their nature, IFRS tend to evolve and adapt to changes in the nature of business transactions over time. In addition to the issues that any nation encounters in the complex process of IFRS adoption, most of the CEEC have, to a greater or lesser extent, specific cultural challenges to overcome.

Countries with cultural accounting values that are more remote from IFRS could find it useful to utilize a variety of ameliorating strategies to adopt and maintain accounting values supportive of IFRS, as follows (Borker, 2012a):

- $\quad$ Establish culturally sensitive education and professional training programs

- $\quad$ Establish culturally focused upgrade programs for existing accounting professionals

- Empower national accounting standard setting bodies to integrate the values of professionalism, flexibility, optimism, and transparency into their professional activities

- $\quad$ Set realistic timeframes and deadlines for the transition to IFRS to allow the local accounting culture to catch up with new IFRS reforms

- Establish a comprehensive change management program for accounting professionals, businesses, government, and the public with necessary change management tools to make a successful transition

- Create robust support infrastructures for IFRS implementation (Borker, 2012b)

Some of these strategies are being applied in countries transitioning to IFRS, particularly where the transition involves moving from relatively different accounting cultures. In the case of Russia, there have been serious efforts made to upgrade the professional and standard setting infrastructure that have been supported by the government and large international accounting firms. 


\section{Other Factors Affecting the Implementation of IFRS}

A variety of other factors, besides underlying cultural and accounting values orientation, influence the successful implementation of IFRS within the CEEC. These factors originate from political, market and economic, and firm-level considerations.

\section{Political Factors}

The CEEC are transitional economies. They have been freed from the personal and economic controls enforced by a non-democratic command economy. At the same time, they have lost the social safety net and military security provided by their former East-bloc membership. Quite naturally, they are all attracted to the relative economic opportunity and stability of European Union membership, even at a time when the EU is experiencing recessions and debt crises. Membership in the EU and NATO also represent a source of security for these relatively small countries living in close proximity to Russia. Consequently, all the CEE countries in this study are at some point in the process of achieving full membership in the European Union.

Given that the EU requires adoption of IFRS for all financial reporting of all EU publically traded companies with implementation beginning in 2005, it is no surprise that all the countries in our CEEC sample require the use of IFRS for financial reporting of large consolidated and separate publically traded companies. When surveyed as to the version of IFRS required, almost all refer to "IFRS as adopted by the European Union" (PWC, 2011). The exception is Serbia which uses its own local version of IFRS based on the not fully completed convergence of Serbian GAAP and IFRS. Everyone in the group that answered the survey prohibits the use of IFRS SME for regulatory reporting of small and medium enterprises (SMEs), in conformity to the EU position, although Estonia has submitted its own version of IFRS SME for EU approval, and in Serbia, its local-based IFRS can be used by any company for regulatory and financial reporting.

Clearly, adoption and implementation of IFRS is significantly influenced by its political importance as a necessary part of the process of achieving the major political goal of full EU membership status and all the benefits obtained from that status.

\section{Market and Economic Factors}

Financial reporting plays an important role in the financial markets of individual countries and in the global financial market. Researchers recognize the economic importance of high quality financial reporting, which can itself be seen as a market commodity for which the demand comes from investors and other users of financial reporting information, and the supply is provided by the reporting and auditing superstructure within and outside of reporting firms (Ball, 2008). Furthermore, an extensive study of firms in 21 different non-U.S. countries that have adopted IFRS (referred to by its former name of IAS in the study) supports the idea that IFRS can improve the quality of financial reporting. Summarized below are some conclusions from the study (Barth, Landsman, \& Lang, 2008).

- $\quad$ The accounting amounts [results] of firms that apply IAS are of higher quality than those of non-U.S. firms that do not apply IAS.

- $\quad$ Firms applying IAS exhibit less earnings smoothing, less management of earnings toward a target, more timely recognition of losses, and a higher association of accounting amounts with share prices and returns.

- IAS firms have a higher accounting quality than firms that do not apply IAS. Differences in accounting quality between the two groups of firms in the period before the firm adopts IAS do not account for the post-adoption differences.

- $\quad$ IAS firms evidence an improvement in accounting quality between the pre- and post-adoption periods.

Given user demand for high quality financial reporting, it is reasonable to assume that the CEEC governments, businesses, and accounting professionals would find it imperative to meet this demand by implementing IFRS. For the CEEC, the adoption of IFRS, in place of local GAAP, potentially represents both a real and perceived improvement in the quality of financial reporting. Such an improvement enhances the prestige of 
auditors and other accounting professionals, increases the confidence of investors, creditors, global analysts, and rating agencies, and ultimately translates into increased potential for capital attraction and growth.

\section{Firm Level Factors}

At the individual firm level, there are many incentives for IFRS financial reporting in an emerging economy. Even disregarding the question of whether a firm's reporting has improved after a change to IFRS, the IFRS label itself can contribute to the company's reputation both domestically and internationally. Specific benefits that have been observed for firms in emerging economies providing financial reporting with high convergence with IFRS are 1) lower share price volatility, 2) lower bid-asked spreads, and 3) higher trading volume (Lima, Sampaio, De Lima, de Cavallio, \& Lima, 2010). All of these features point to greater trading efficiency and liquidity of share price for the firms and their investors. Other advantages that can be assumed or hypothesized are a lowering of the firm's cost of capital, an improvement in equity and debt evaluations by analysts and rating agencies and, consequently, greater potential to raise equity and debt capital for growth and expansion. With the fairer valuation of net assets and income under IFRS, it has been argued that the differential between market and book equity values will be closer. Naturally, differences will remain at some level to reflect the investor growth assumptions implicit in price/earnings ratios. These ratios should, however, be truer and more reliable as measures of expected growth since other distractions are minimized with IFRS.

\section{CONCLUSION}

The findings of this study indicate that, based on cultural factors, the CEEC group can be divided into two distinct accounting orientations - one very similar to the accounting values attributable to Russia and most remote from the accounting values associated with IFRS and the other with cultural affinities more in line with IFRS, possibly reflected in cultural affinities to either Germany or Scandinavian countries. This seems to indicate that countries in the first group may have more cultural issues to overcome in the implementation of IFRS. To the extent that such issues manifest themselves as a material factor in the successful implementation of IFRS, an emphasis should be placed on finding solutions in the areas of professional training, accounting education, change management methods, and any other methods that insure the development of an independent and professional accounting infrastructure and enlightened investors and other user of financial reporting.

What also stands out is the great importance of external and internal factors, particularly of a political, market/economic and firm incentive-level nature in determining the successful implementation of IFRS in the CEEC. The priority of attaining full EU membership alone is a significant external factor exerting a positive influence on IFRS implementation. The CEE countries and their individual firms are aware of the global demand for high quality financial reporting and the potential rewards in terms of global reputation and ability to efficiently raise capital in a global marketplace. Nonetheless, even though all CEEC may be highly motivated to successfully achieve IFRS implementation, the subtle forces of cultural values and orientations must not be overlooked as potential "bumps in the road" needing repair. In this regard, special attention should be paid to the CEEC in the Balkan region to be sure that they are afforded the educational and professional support needed to achieve their economic and political goals. Further research and monitoring of the implementation of IFRS in the CEEC is an important direction, both for international accounting research and for general research on accounting in the CEEC region.

\section{AUTHOR INFORMATION}

David Borker has a PhD from Yale with a Master of Accounting/MBA from Ohio State University and an A.B. from Cornell. By his academic and corporate/consulting experience, Dr. Borker is uniquely suited for accounting and business research on Russia, the CIS republics and Eastern Europe. A native speaker of English, he is fluent in Russian, German and Czech and uses numerous other languages in his research. Dr. Borker has extensive experience as an academic consultant and a businessman working in Russia, Eastern Europe and the CIS. He teaches accounting and management at Manhattanville College and is a licensed CPA. E-mail: David.Borker@mville.edu 


\section{REFERENCES}

1. Albu, C. N., Albu, N., Gerbina, M., Bonaci, C. G., \& Mustata, R. (2011). Financial Reporting in Romania. In J. Strouhal (Ed.), Harmoniation of SME's Financial Reporting in Emerging CEE Countries (pp. 219262). SWEAS Press.

2. Albu, N., Albu, C. N., Bunea, S., Calu, D. A., \& Girbina, M. M. (2011). A Story about IAS/IFRS Implementation in Romania. Journal of Accounting in Emerging Countries. doi: $10.1108 / 20421161111107868$

3. Alver, J., \& Alver, L. (2011). Financial Reporting in Estonia. In J. Strouhal (Ed.), Harmonization of SME's Financial Reporting in Emerging CEE Countries (pp. 70-137). WSEAS Press.

4. Andric, M., Mijic, K., \& Jaksic , D. (2011). Financial Reporting and Characteristics of Impairment of Assets in the Republic of Serbia, According to IAS/IFRS and National Regulation. Economic Annals, 56(189), 101-116.

5. Ball, R. (2008). What is the Actual Economic Role of Financial Reporting? Accounting Horizons, 22(4), 427-432.

6. Baloghova, B. (2008). Information Gained from the Financial Statements - the Scope for Judgement of Property and Financial Situation in Enterprises in Slovakia and in the United Kingdom. Zeszyty Naukowe. Organizacja i Zarządzanie / Politechnika Ślaska, 47, 81-89.

7. Barac, Z. A., \& Klepo, T. (2006). Features of Accounts Manipulations in Croatia. Zb. rad. Ekon. fak. Rij, 24(2), 273-290. Retrieved from http://www.efri.uniri.hr/admin/dokumenti/06 aljinovic.pdf

8. Barac, Z. A., \& Reljanovic, K. (2012). Independence of Accounting Provsions and Company's Financial Performance. The Business Review, Cambridge, 19(2), 94-100.

9. Barth, M. E., Landsman, W. R., \& Lang, M. H. (2008). International Accounting Standards and Accounting Quality. Journal of Accounting Research, 46(3), 1-33.

10. Baskerville, R. (2003). Hofstede Never Studied Culture. Accounting, Organizations and Society, 28(1), 114.

11. Baydoun, N., \& Willet, R. (1995). Cultural Relevance of Western Accounting Systems to Developing Countries. ABACUS, 31(1), 67-92.

12. Beke, J. (2011). International Accounting Standardization Practice in Hungary. Regional and Business Studies, 3(1).

13. Blechova, B. (2011). Financial Reporting in Poland. In J. Strouhal (Ed.), Harmoniation of SME's Financial Reporting in Emerging CEE Countries (pp. 169-217). WSEAS Press.

14. Boerstler, C. (2006). Zur Zukunft der externen Rechnungslegung in Deutschland. Wiesbaden: Deutscher Universitaets-Verlag.

15. Bogdan, D., \& Stefana-Maria, C. (2009). A Discussion on New Cultural Transformations. Transformations Monétaires et Financières dans les Pays d'Europe Centrale et Orientale, 11, pp. 103-129.

16. Bogdan, V., \& Cristea, S.-M. (2009). Particularities of Accounting Regulatory Process in Several Eastern European Former Soviet Union Countries. Oradea.ro, 973-982.

17. Borker, D. R. (2012a). Accounting, Culture And Emerging Economies: IFRS In The BRIC Countries. Journal of Business and Economics Research, 5, 313-324.

18. Borker, D. R. (2012b). Stepped-Up Progress On IFRS In Russia: History In The Making. International Business \& Economics Research Journal, 11(2), 255-268.

19. Borker, D. R. (manuscript). Is There a Favorable Cultural Profile for IFRS?: An Examination and Extension of Gray's Accounting Value Hypotheses.

20. Buys, P. W., \& Schutte, D. (2011). A Consideration Of IFRS Education. International Business \& Economics Research Journal, 10(12), 49-58.

21. Cernius, G. (2011). Confusion of Accounting Terminology in Lithuanaia. European Journal of Business and Economics , 3, 12-16.

22. Chanchani, S., \& MacGregor, S. (1999). A Synthesis of Cultural Studies in Accounting. Journal of Accounting, 18, 1-30.

23. Chanchani, S., \& Willet, R. (2004). An Empirical Assessment of Gray's Accounting Value Constructs. International Journal of Accounting, 39(2), 125-154.

24. Doupnik, T., \& Tsakumis, G. (2004). A Critical Review of Tests of Gray's Theory of Cultural Relevance and Suggestions for Future Research. Journal of Accounting Literature, 23, 1-48. 
25. Dragojević, D. P., Milenovic, M., \& Simic, M. (2006). Efekti Računovodstvenog Zakonodavstva Srbije kod Primene IFRS Standarda u Tranzicionom Procesu. Revizor, 9(35), 53-61.

26. Emenyonu, E., \& Gray, S. (1992). EC Accounting Harmonisation: An Empirical Study of Measurement Practices in France, Germany and the UK. Accounting and Business Research, 23(89), 49.

27. European Value Studies Group, \& World Values Survey Association. (2006). European and World Values Surveys Four-Wave Integrated Data File 1981-2004.

28. Finch, N. (2009). Towards an Understanding of Cultural Influence on the International Practice of Accounting. Journal of International Business and Cultural Studies.

29. Garrod, N., \& Turk, I. (1995). The development of accounting regulation in Slovenia. European Accounting Review, 4(4), 749-764. doi:10.1080/09638189500000048

30. Gray, S., \& Vint, H. (1995). The Impact of Culture on Accounting Disclosures: Some International Evidence. Asia-Pacific Journal of Accounting, 21, 33-43.

31. Gray., S. J. (1988). Towards a Theory of Cultural Influence on the Development of Accounting Systems Internationally. Abacus, 24(1), 9-11, 12.

32. Hodstede, G., \& Bond, M. (1988). The Confucius Connection: From Cultural Foots to Economic Growth. Organisational Dynamics, 16(1), 5-21.

33. Hofstede, G. (1980). Cultures Consequences: International Differences in Work Related Values. Newbury Park, NJ: Sage.

34. Hofstede, G. (1994). The Pitfalls of Cross-National Survey Research: A Reply to the Article by Spector et al. on the Psychometric Properties of the Hofstede Values Survey Module 1994. Applied Psychology, 51(1), 170-173.

35. Hofstede, G. (2001). Culture's Consequeces: Comparing Values, Behaviors, Institutions, and Organizations across Nations (2 ed. ed.). Thousand Oaks, London, New Delhi: Sage Publications.

36. Hofstede, G., Hofstede, G. J., \& Minkov, M. (2010). Cultures and Organizations: Software of the Mind: Intercultural Cooperation and its Importance for Survival. New York: McGrawHill.

37. Hope, O-K. (2003). Firm-level Disclosures and the Relative Roles of Culture and Legal Origin. . Journal of International Financial Management and Accounting, 14, 218-248.

38. Hoskisson, R. E., Eden, L., Lau, C. M., \& Wright, M. (2000). Strategy in Emerging Economies. Academy of Management Journal, 43(3), 249-267.

39. Huang, Y. (2007). Relationships Between National Cultures and Hofstede Model, and Implications for a Multinational Enterprise. 13th Asia Pacific Management Conference (2007), 1422-1428.

40. Kovacic, D. (2010). External Reporting in Republic of Croatia. Accounting Act-Registry of Annual Financial. Reports. Retrieved from http://siteresources.worldbank.org/EXTCENFINREPREF/Resources/4152117-1277976014693/72146691280512989897/dragutin_covacic_eng.pdf

41. Larson, R. K., \& Street, D. L. (2001). Convergence with IFRS in an Expanding Europe:progress and Obstacles Identified by Large Accounting Firms' Survey. Journal of International Accounting, Auditing and Taxation, 13, 89-119.

42. Lerman, Z., Csaki, C., \& Feder, G. (2004). Agriculture in Transition: Land Policies and Evolving Farm Structures in Post-Soviet Countries. Lanham, MD: Lexington Books.

43. Lima, V. S., Sampaio, G. A., De Lima, F., de Cavallio, N. G., \& Lima, I. S. (2010). Toward IFRS: Economic Consequences of Accounting Convergence in an Emerging Economy. Research in Emerging Economies, 10, 251-295.

44. Mackevicius, J., Zverovich, S., \& Kaslauskiene, L. (2011). Financial Reporting in Lithuania. In J. Strouhal, Harmoniation of SME's Financial Reporting in Emerging CEE Countries (pp. 138-168). WSEAS Press.

45. McGee, R. W. (2008). Corporate Governance in Transition Economies. Google E-book.

46. Moczarska, L. (2009). Adoption, Acceptance and Operationalisation of IFRS/IAS in Poland - The Significance of Historical and Cultural Factors. Maastricht: Univesity of Maastricht Masters Thesis in Accounting.

47. Mosnja-Skare, L. (2001). Globalisation Impact on Accounting Transition in Croatia. Ekonomski Pregled, 52(3-4), 431-445.

48. Murphy, D. S. (2009). The Evolution of Public Sector Financial Management in Bulgaria. International Journal of Managerial and Financial Accounting, 1(4), 370-378.1 
49. Pasekova, M. (2011). Financial Reporting in Slovakia. In J. Strouhal (Ed.), Harmoniation of SME's Financial Reporting in Emerging CEE Countries (pp. 263-306). WSEAS Press.

50. Paupa, V. (2006). The Development of Systematic Supervision of Accounting in Latvia since Returning of Independence. Vadyba/Management, 2(11), 112-122. Retrieved from https://docs.google.com/viewer?a=v\&q=cache:yCZkGxxEWIcJ:www.leidykla.vu.lt/fileadmin/Vadyba/11/ Vilma_Paupa_Arturs_Praulins.pdf+LATVIA+ACCOUNTING\&hl=en\&gl=us\&pid=bl\&srcid=ADGEESh mIxFvwq3VvsCfLjaWTfmZY17hsUllbTz-W07xwgdwBQMQjIlwPygfqY9RkABDaR8KJbzfN_R4ucRw

51. Perera, H. (1989). Towards a framework to analyze the impact of culture on accounting. The International Journal of Accounting, 24, 42-56.

52. Pervan, I. (2012). Utilization of Accounting Information for Decision making in Croatian SME: Preliminary Findings. The Business Review, Cambridge, 19(2), 165-171.

53. Plaats, E. v., \& Nagy, D. (2011). Croatia Report on the Observance of Standards and Codes (ROSC) Accounting and Auditing. World Bank Report. World Bank Group. Retrieved from Permanent URL for this page: http://go.worldbank.org/8OMKB6S9A0

54. PWC. (2011). IFRS Adoption by Country. PriceWaterhouseCoopers LLP. Retrieved May 24, 2012, from http://www.pwc.com/us/en/issues/ifrs-reporting/country-adoption

55. Randelj, N. (2008). Economic Objects as Cultural Objects: Discourse on Foreign Investment in Postsocialist Europe. Socioeconomic Revue, 6(4), 671-702.

56. Salter, S., \& Niswander, F. (1995). Cultural Influence on the Development of Accounting Systems Internationally: A Test of Gray's [1988] Theory. Journal of International Business Studies, 26(2), 379-397.

57. Sondergaard, M. (1994). Hofstede's consequences: A study of reviews, citations and replications. Organization Studies, 15(3), 447-456.

58. Spector, P. E. (2001). Relationships Between National Cultures and Hofstede Model, and Implications For A Multinational Enterprise. Applied Psychology" An International Review, 50(2), 269-281.

59. Strouhal, J. (2011). Financial Reporting in the Czech Republic. In J. Strouhal (Ed.), Harmoniation of SME's Financial Reporting in Emerging CEE Countries (pp. 34-70). WSEAS Press (World Scientific and Engineering Academy and Society).

60. Strouhal, J., Dvorakova, D., \& Pasekova, M. (2011). European Harmionization of SME's Financial Reportimng. In J. Strouhal (Ed.), Harmoniation of SME's Financial Reporting in Emerging CEE Countries (pp. 1-14). SWEAS Press.

61. Sucher, P., \& Jindrichovska, I. (2004). Implementing IFRS: A Case Study of the Czech Republic. Accounting in Europe, I, 109-141.

62. World_Bank. (2005). Report on the Observance of Standards and Codes (ROSC) Republic of Latvia. World Bank Group. Retrieved from https://docs.google.com/viewer?a=v\&q=cache:L8rtelGNlkJ:www.worldbank.org/ifa/rosc_aa_lat.pdf+LATVIA+ACCOUNTING\&hl=en\&gl=us\&pid=bl\&srci d=ADGEESj1RwTWhNdMuVLaIEBCaDNmA_FZqV99VX_FHbcXYkoVfMY7En7HWT25oVotdLwjH2XZ60k66h10bf0mYH3uvA4lFvY1ghbO-jUZ0I-V2KkwlIZ8

63. Zarzeski, M. T. (1996). Spontaneous Harmonization Effects of Culture and Market Forces on Accounting Disclosure Practices. Accounting Horizons, 10, 18-37. 
NOTES 